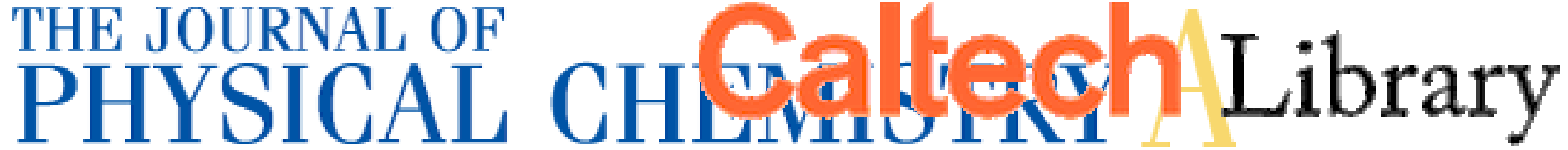

Subscriber access provided by Caltech Library

\section{Article}

Reactions of Criegee Intermediates with Alcohols at Air-Aqueous Interfaces

Shinichi Enami, and Agustin J. Colussi

J. Phys. Chem. A, Just Accepted Manuscript • DOI: 10.1021/acs.jpca.7b04272 • Publication Date (Web): 21 Jun 2017

Downloaded from http://pubs.acs.org on June 23, 2017

\section{Just Accepted}

"Just Accepted" manuscripts have been peer-reviewed and accepted for publication. They are posted online prior to technical editing, formatting for publication and author proofing. The American Chemical Society provides "Just Accepted" as a free service to the research community to expedite the dissemination of scientific material as soon as possible after acceptance. "Just Accepted" manuscripts appear in full in PDF format accompanied by an HTML abstract. "Just Accepted" manuscripts have been fully peer reviewed, but should not be considered the official version of record. They are accessible to all readers and citable by the Digital Object Identifier (DOI®). "Just Accepted" is an optional service offered to authors. Therefore, the "Just Accepted" Web site may not include all articles that will be published in the journal. After a manuscript is technically edited and formatted, it will be removed from the "Just Accepted" Web site and published as an ASAP article. Note that technical editing may introduce minor changes to the manuscript text and/or graphics which could affect content, and all legal disclaimers and ethical guidelines that apply to the journal pertain. ACS cannot be held responsible for errors or consequences arising from the use of information contained in these "Just Accepted" manuscripts. 


\title{
Reactions of Criegee Intermediates with Alcohols at Air-Aqueous Interfaces
}

\author{
Shinichi Enami*a and A. J. Colussi* ${ }^{\mathrm{b}}$ \\ ${ }^{a}$ National Institute for Environmental Studies, 16-2 Onogawa, Tsukuba, Ibaraki 305-8506, Japan \\ ${ }^{b}$ Linde Center for Global Environmental Science, California Institute of Technology, Pasadena, California
} 91125, USA.

*Authors to whom correspondence should be addressed: S.E. enami.shinichi@nies.go.jp, phone: +81-29-850-2770 or A.J.C. ajcoluss@caltech.edu, phone: +1-626-395-6350

\begin{abstract}
-
The fate of Criegee intermediates (Cls) from the gas-phase ozonolysis of unsaturated organic compounds in the troposphere is largely controlled by their reactions with water vapor. We recently found that against all expectations carboxylic acids compete at millimolar concentrations with water for $\mathrm{Cls}$ at the air-liquid interface of aqueous organic media. This outcome is consistent with both the low water concentration in the outermost interfacial layers and the enrichment of the competing acids therein. Here we show, via on-line electrospray mass spectrometric detection, that $\mathrm{Cl}$ generated in situ in the fast ozonolysis of sesquiterpenes $\left(\mathrm{C}_{15} \mathrm{H}_{24}\right)$ on the surface of water:acetonitrile microjets react with $\mathrm{n} \geq 4$ linear alcohols $\mathrm{C}_{n} \mathrm{H}_{2 n+1} \mathrm{OH}$ to produce high molecular weight $\mathrm{C}_{n+15}$ ethers in one-step. The OH-group of 1-octanol proved to be $\sim 25$ times less reactive than that of n-octanoic towards $\mathrm{Cls}$ at the same bulk molar concentration, revealing that the reactivity of hydroxylic species both depends on acidities and interfacial affinities. Cls interfacial reactions with surface-active hydroxylic species, by bypassing water, represent shortcuts to molecular complexity in atmospheric aerosols.
\end{abstract}




\section{INTRODUCTION}

Ozonolysis of unsaturated hydrocarbons (such as those from massive biogenic terpene emissions) is the leading source of Criegee intermediates $(\mathrm{Cls})^{1}$ in the atmosphere. $\mathrm{Cls}$ have a major role in atmospheric $\mathrm{HOx}$ cycling and in particle formation, particularly over forests. ${ }^{2-11}$ Unsaturated hydrocarbons are also deemed to be reactively uptaken on the surface of acidic aerosols and leaf films, ${ }^{12-14}$ where they would react with $\mathrm{O}_{3}(\mathrm{~g})$ to generate $\mathrm{Cls}$ therein. ${ }^{15-16}$ The fate of the Cls generated on the surface of aqueous organic aerosols, however, is not known. Theoretical calculations predicted that the reaction of the smallest $\mathrm{Cl}\left(\mathrm{CH}_{2} \mathrm{OO}\right)$ with water molecules at the air-water interface would proceed $\sim 10^{2}-10^{3}$ faster than in the gas-phase. ${ }^{17}$ In this regard, we recently found that in the outermost interfacial layers of water/acetonitrile mixtures, as surrogates of aqueous organic aerosol media, long-chain carboxylic acids at millimolar concentrations compete with $\left(\mathrm{H}_{2} \mathrm{O}\right)_{n}$ for $\mathrm{Cls}^{18}$ We ascribed this finding to the low water concentrations prevalent in the outermost interfacial layers of such mixtures, and to the surface enrichment of the more hydrophobic carboxylic acids. We also found that surface-active cis-pinonic acid (CPA), a major product of the ozonolysis of biogenic monoterpenes, is a particularly reactive scavenger of $\mathrm{Cls}$ on aqueous surfaces, due to its peculiar molecular geometry that places the reactive hydroxylic $\mathrm{C}(\mathrm{O})-\mathrm{OH}$ group close to the interface. ${ }^{19}$ Our findings are the more remarkable because in the gas-phase $\mathrm{CH}_{2} \mathrm{OO}$ reacts with $\left(\mathrm{H}_{2} \mathrm{O}\right)_{2}$ and $\mathrm{C}_{1}-\mathrm{C}_{2}$ carboxylic acids at large rate constant $\sim 10^{-11}$ and $\sim 10^{-10} \mathrm{~cm}^{3}$ molecule $\mathrm{s}^{-1}$ respectively. ${ }^{20-22}$ The fact that $\mathrm{Cls}$ react with organic hydroxylic species in competition with water at air-aqueous interfaces bears directly on the mechanism of organic aerosol accretion and growth, because it amounts to a one-step polymerization process involving large molecules that has not been hitherto considered in chemical models 
of secondary organic aerosol formation. ${ }^{23}$

Here we report the first direct detection of intermediates and products from atmospherically relevant alcohols $\mathrm{C}_{n} \mathrm{H}_{2 n+1} \mathrm{OH}(n=1-8)$ reactions with $\mathrm{Cls}$ generated on fresh surfaces of $\beta$-caryophyllene $(\beta-C)$ and $\alpha$-humulene $(\alpha-H)$ solutions in acetonitrile (AN): water (W) exposed to $\mathrm{O}_{3}(\mathrm{~g})$ for $\sim 10 \mu \mathrm{s}$. Long-chain alcohols are ubiquitous surfactants found in a variety of atmospheric aerosol and sea-surface microlayers ${ }^{24-28}$ and, therefore, their reactions with $\mathrm{Cls}$ will contribute to the formation and augmentation of the chemical complexity of atmospheric particles and organic microfilms.

\section{EXPERIMENTAL SECTION}

The experimental setup is essentially the same as that reported elsewhere. ${ }^{18,29} \mathrm{~A}$ brief description follows. We inject [sesquiterpene $(\beta-\mathrm{C}$ or $\alpha-\mathrm{H})+$ alcohol $+\mathrm{NaCl}$ ] solutions in acetonitrile:water $(\mathrm{AN}: \mathrm{W}=4: 1=$ vol:vol) as microjets into the spraying chamber of an electrospray mass spectrometer (ES-MS, Agilent 6130 Quadrupole LC/MS Electrospray System at NIES, Japan) flushed with $\mathrm{N}_{2}(\mathrm{~g})$ at $1 \mathrm{~atm}, 298 \mathrm{~K}$. We chose sesquiterpenes as in situ sources of $\mathrm{Cls}$ due to their high reactivity toward $\mathrm{O}_{3}(\mathrm{~g}),{ }^{30}$ which makes them compatible with the short $\tau_{\mathrm{R}} \sim 10 \mu$ s contact times of our experiments. ${ }^{31-33}$ We use a AN:W solvent mixture as surrogate of atmospheric aqueous organic aerosols because the composition of its interfacial layers is well characterized by both theory and experiments. ${ }^{34-35}$ Microjets are exposed to an orthogonal $\mathrm{O}_{3}(\mathrm{~g})$ beam (Fig. 1). 


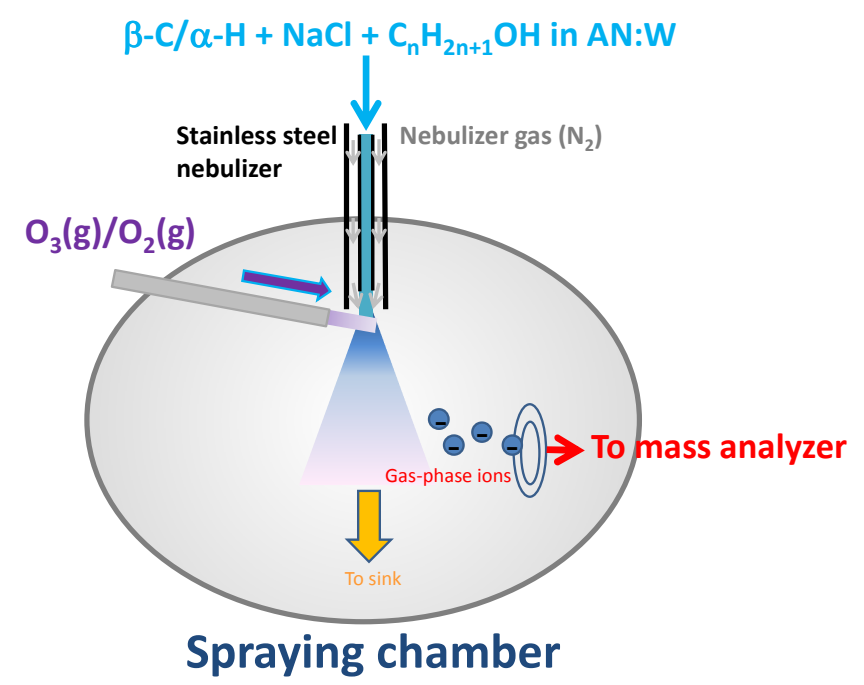

Figure 1 - Schematic diagram of the experimental setup. $\beta-C, \alpha-H, A N$ and $W$ stand for $\beta$-caryophyllene, $\alpha$-humulene, acetonitrile and water, respectively.

AN:W solutions are pumped (at $100 \mu \mathrm{L} \mathrm{min}^{-1}$ ) into the spraying chamber through a grounded stainless steel needle (100 $\mu \mathrm{m}$ bore) coaxial with a sheath issuing nebulizer $\mathrm{N}_{2}(\mathrm{~g})$ at high velocity $v_{\mathrm{g}}\left(\sim 160\right.$ meter $\left.\sec ^{-1}\right) .^{36}$ The species detected by ES mass spectrometry are produced in $\mathrm{O}_{3}(\mathrm{~g})$ reactive collisions with the surface of the microjets as they emerge from the grounded nozzle. ${ }^{31}$ Previous experiments in our laboratory have demonstrated that mass spectral signal intensities are proportional to interfacial ion populations. ${ }^{31-32,36}$ We have shown that mass spectra: (1) are not affected by the weak local electric fields at the tip of the grounded nozzle, ${ }^{37-38}$ (2) correspond to species generated by reactions taking place in the outermost interfacial layers of the microjets. ${ }^{29,31-32,39-40}$ The limited exposures of microjets to $\mathrm{O}_{3}(\mathrm{~g})$ during the short contact times of our experiments: $E=\left[\mathrm{O}_{3}(\mathrm{~g})\right] \times \tau_{\mathrm{R}} \leq 2.4 \mathrm{x}$ $10^{11}$ molecules $\mathrm{cm}^{-3} \mathrm{~s}$, enables us to monitor the earliest reactive events undergone by the $\mathrm{Cls}$ generated right at the liquid surface. Note that in our experiments the addition of $\mathrm{NaCl}$ lets us detect neutral species as negatively charged chloride-adducts, which are 
unambiguously identified by the characteristic $M / M+2=3 / 1$ signal ratios arising from natural abundance ${ }^{35} \mathrm{Cl}:{ }^{37} \mathrm{Cl}:: 0.75: 025$ isotopes. We verified that chloride is inert towards $\mathrm{O}_{3}(\mathrm{~g})$ under present conditions. ${ }^{41-42}$ Further experimental details can be found in previous publications. $^{18,29,32-33,36,40,43}$

Ozone was generated by flowing ultrapure $\mathrm{O}_{2}(\mathrm{~g})(>99.999 \%)$ through a silent discharge ozonizer (KSQ-050, Kotohira, Japan) and quantified by online absorption spectrophotometry at 250 or $300 \mathrm{~nm}$ (Agilent 8453) prior to entering the reaction chamber. The reported $\left[\mathrm{O}_{3}(\mathrm{~g})\right]$ correspond to the concentrations sensed by the microjets, which are $\sim 12$ times smaller than the $\left[\mathrm{O}_{3}(\mathrm{~g})\right]$ determined by spectrophotometry due to dilution by the drying $\mathrm{N}_{2}$ gas-flow. Conditions in the present experiments were: drying $\mathrm{N}_{2}$ gas-flow rate: $12 \mathrm{~L} \mathrm{~min}^{-1}$; drying $\mathrm{N}_{2}$ gas temperature: $340{ }^{\circ} \mathrm{C}$; inlet electric potential: $+3.5 \mathrm{kV}$ relative to ground; fragmentor polarization: $60 \mathrm{~V}$. All solutions were prepared in Milli-Q water (Resistivity $\geq 18.2 \mathrm{M} \Omega \mathrm{cm}$ ) and used within 48 h. $\beta$-caryophyllene ( $\geq 98.5 \%$, Sigma-Aldrich), $\alpha$-humulene ( $\geq 96.0 \%$, Sigma-Aldrich), methanol ( $\geq 99.9 \%$, Sigma-Aldrich), ethanol ( $\geq 99.5 \%$, Wako), 1-propanol $(\geq$ $99.7 \%$, Wako), 1-butanol ( $\geq 99.9 \%$, Sigma-Aldrich), 1-pentanol ( $\geq 99 \%$, Sigma-Aldrich), 1-hexanol ( $\geq 97 \%$, Wako), 1-heptanol ( $\geq 98 \%$, Wako), 1-octanol ( $\geq 99 \%$, Sigma-Aldrich), n-octanoic acid ( $\geq 97 \%$, Wako), acetonitrile ( $\geq 99.8 \%$, Wako), $\mathrm{D}_{2} \mathrm{O}(99.9$ atom \% D, Sigma-Aldrich), $\mathrm{H}_{2}{ }^{18} \mathrm{O}$ (97\%, Santa Cruz Isotope), and $\mathrm{NaCl}(\geq 99.999 \%$, Sigma-Aldrich) were used as received.

\section{RESULTS AND DISCUSSION}

Fig. 2 shows negative ion electrospray mass spectrum of $[1 \mathrm{mM} \beta-\mathrm{C}+0.2 \mathrm{mM} \mathrm{NaCl}+100$ $\mathrm{mM}$ 1-octanol] in $\mathrm{AN}: \mathrm{W}(4: 1=\mathrm{vol}: \mathrm{vol})$ microjets in the absence and presence of $\mathrm{O}_{3}(\mathrm{~g})$. 


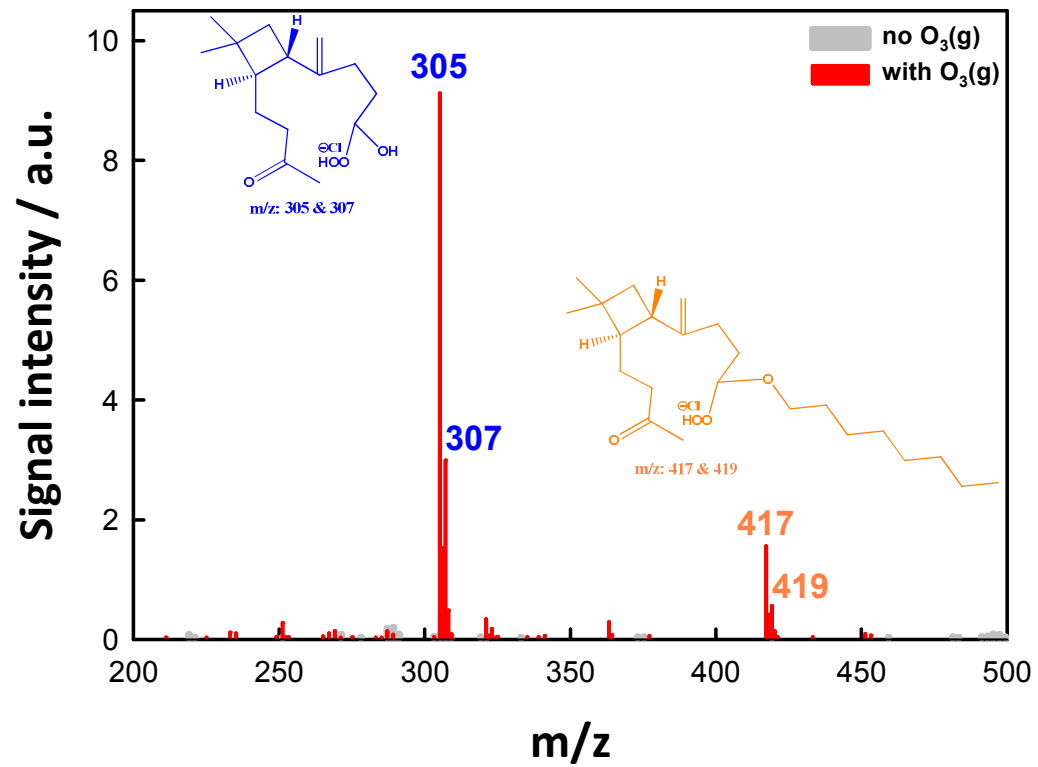

Figure 2 - Negative ion electrospray mass spectra of $[1 \mathrm{mM} \beta-\mathrm{C}+0.2 \mathrm{mM} \mathrm{NaCl}+100 \mathrm{mM}$ 1-octanol $]$ in $\mathrm{AN}: \mathrm{W}(4: 1=\mathrm{vol}: \mathrm{vol})$ microjets before (gray) and after (red) being exposed to $\mathrm{O}_{3}(\mathrm{~g})\left(E=4.1 \times 10^{10}\right.$ molecules $\left.\mathrm{cm}^{-3} \mathrm{~s}\right)$ in $1 \mathrm{~atm} \mathrm{~N}_{2}(\mathrm{~g})$ at $298 \mathrm{~K}$. The $\mathrm{m} / \mathrm{z} 305 ; 307$ and 417;419 signals correspond to chloride-adducts of $\mathrm{C}_{15} \alpha$-hydroxy-hydroperoxides and $\mathrm{C}_{23} \alpha$-alkoxy-hydroperoxides, respectively. We show the representative structures of possible isomers. See text for details.

In the presence of $\mathrm{O}_{3}(\mathrm{~g})$, intense peaks appear at $\mathrm{m} / \mathrm{z} 305 ; 307$ and $417 ; 419$ in $\mathrm{M} / \mathrm{M}+2=3 / 1$ $={ }^{35} \mathrm{Cl} /{ }^{37} \mathrm{Cl}$ ratios (Fig. 2). We had found that the ozonolysis of $\beta-\mathrm{C}$ on $\mathrm{AN}: \mathrm{W}$ surfaces proceeds $\sim 20$ times faster than in the bulk liquid saturated with ozone, ${ }^{30}$ and orders of magnitude faster than in the gas-phase. ${ }^{10,44}$ We confirmed that 1-octanol is inert toward $\mathrm{O}_{3}(\mathrm{~g})$ under present conditions (Fig. S1), in accordance with the negligibly small rate constant: $k_{03+1-o c t a n o l} \leq 0.8 \mathrm{M}^{-1} \mathrm{~s}^{-1}$ in bulk water. ${ }^{45}$ The $\mathrm{m} / \mathrm{z} 305 ; 307$ signals correspond to species resulting from the addition of $\mathrm{O}_{3}(+48)$ to a $\beta-\mathrm{C}(\mathrm{MW}=204)$ endo $\mathrm{C}=\mathrm{C}$ bond, ${ }^{10,30}$ followed by the addition of $\mathrm{H}_{2} \mathrm{O}(+18)$ and detected as chloride-adducts: $305(307)=204+$ $48+18+35$ (37). ${ }^{18}$ Our observation that (neutral) hydroperoxides form detectable chloride-adducts is in line with the reported strong affinity of chloride for such species. ${ }^{7,46-47}$ 
The $\mathrm{m} / \mathrm{z} 417 ; 419$ signals correspond to the products of 1 -octanol $(\mathrm{MW}=130$ ) addition to Cls: $417(419)=204+48+130+35(37)($ Scheme 1$)$.

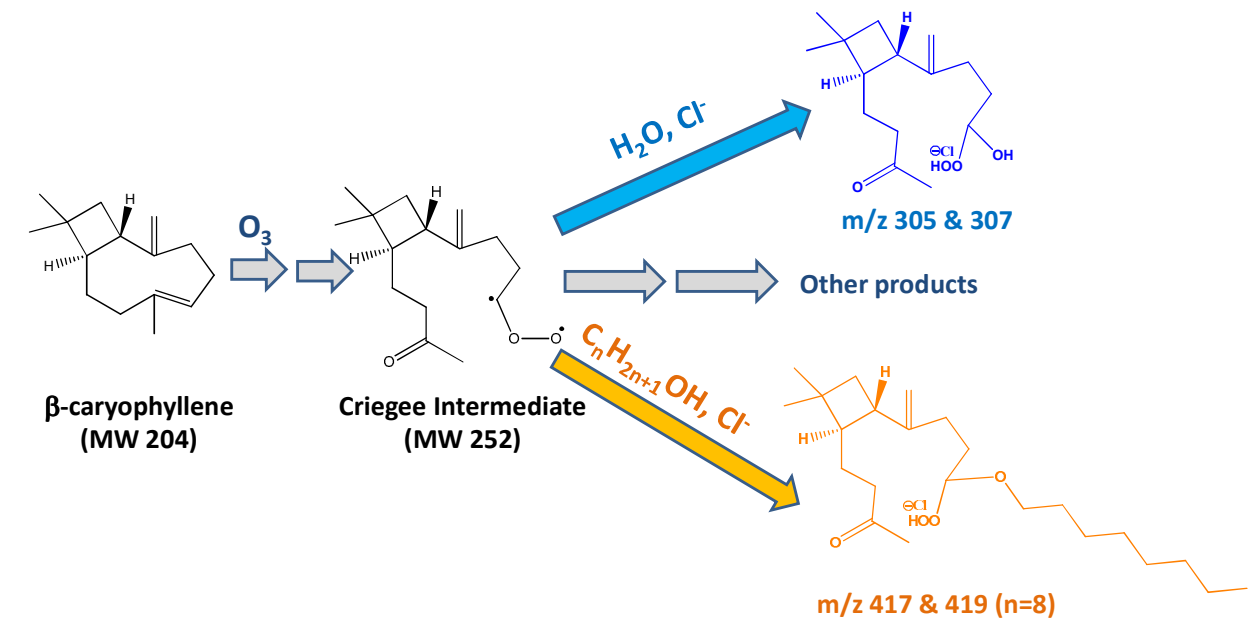

SCHEME 1: Reaction mechanism of $\beta$-caryophyllene's Criegee intermediate $+n$-alkanols at air-aqueous interfaces. Here we show representative structures among possible isomers.

Thus, the $\mathrm{m} / \mathrm{z} 417 ; 419$ signals are assigned to the $\alpha$-alkoxy-hydroperoxides $\left(\mathrm{C}_{23}\right.$ ethers) produced from Cls reactions with 1-octanol (Scheme 1). As mentioned above, we recently found that carboxylic acids $\mathrm{R}_{\mathrm{n}}-\mathrm{COOH}\left(\mathrm{n} \geq 4\right.$ ) and a surface-active $\mathrm{C}_{10}$ keto-carboxylic acid at $\mathrm{mM}$ concentrations are able to compete with interfacial water molecules for the Cls derived from the ozonolysis of $\beta-\mathrm{C}$ or $\alpha-\mathrm{H}$ on the surface of $\mathrm{AN}: \mathrm{W}^{18-19}$ Here we find that 1-octanol also competes with interfacial water for Cls to generate a higher mass product (MW 382, detected as $\mathrm{m} / \mathrm{z} 417$ and 419 ) than the $\mathrm{m} / \mathrm{z}=305 \alpha$-hydroxy-hydroperoxides resulting from Cls reactions with $\left(\mathrm{H}_{2} \mathrm{O}\right)_{n}$. Similarly, in experiments involving shorter-chain alcohols at the same molar concentrations (Figs. S2 and S3), we detect smaller signals at $\mathrm{m} / \mathrm{z}=204+48+$ $\mathrm{MW}\left(\mathrm{R}_{\mathrm{n}} \mathrm{H}_{2 \mathrm{n}+1} \mathrm{OH}, 4 \leq \mathrm{n} \leq 7\right)+35(37)$ where signal intensity decreases as $n$ decreases (see below). The formation of $\alpha$-alkoxy-hydroperoxides from Cls reactions with alcohols is consistent with reports on ozonolyses in the gas and bulk liquid phases. ${ }^{5,48-52,53}$ To our knowledge, this is the first-time report that $\alpha$-alkoxy-hydroperoxides are produced from $\mathrm{Cls}$ reactions with alcohols in the presence of excess water at air-aqueous interfaces. Our 
results suggest the involvement of interfacial Cls chemistry in the prompt generation of molecular complexity on aqueous organic surfaces. Note that $\alpha$-hydroxy-hydroperoxides and $\alpha$-alkoxy-hydroperoxides are much less volatile than their precursors, and can further extend this process into even less volatile species via free radical polymerizations upon thermal or photochemical $\mathrm{O}-\mathrm{OH}$ bond dissociation, ${ }^{54-55}$ or by addition to $\mathrm{Cls}^{3,23}$ Peaks at $\mathrm{m} / \mathrm{z}$ $305 ; 307$ and $417 ; 419$ appear both in the ozonolysis of $\beta-\mathrm{C}$ and $\alpha-\mathrm{H}$ in the presence of 1-octanol (Fig. S4), thereby implying that Cls generated in situ will generally react with long-chain alcohols on aqueous organic surfaces. ${ }^{56-59}$

Additional evidence on the identity and mechanisms of formation of the observed products was obtained from negative ion electrospray mass spectrometry of $[\beta-\mathrm{C}+\mathrm{NaCl}+$ 1-octanol] in $\mathrm{AN}: \mathrm{D}_{2} \mathrm{O}$ (Fig. $3 \mathrm{~A}$ ) and $\mathrm{AN}: \mathrm{H}_{2}{ }^{18} \mathrm{O}$ (Fig. 3B) microjets in the absence and presence of $\mathrm{O}_{3}(\mathrm{~g})$. 


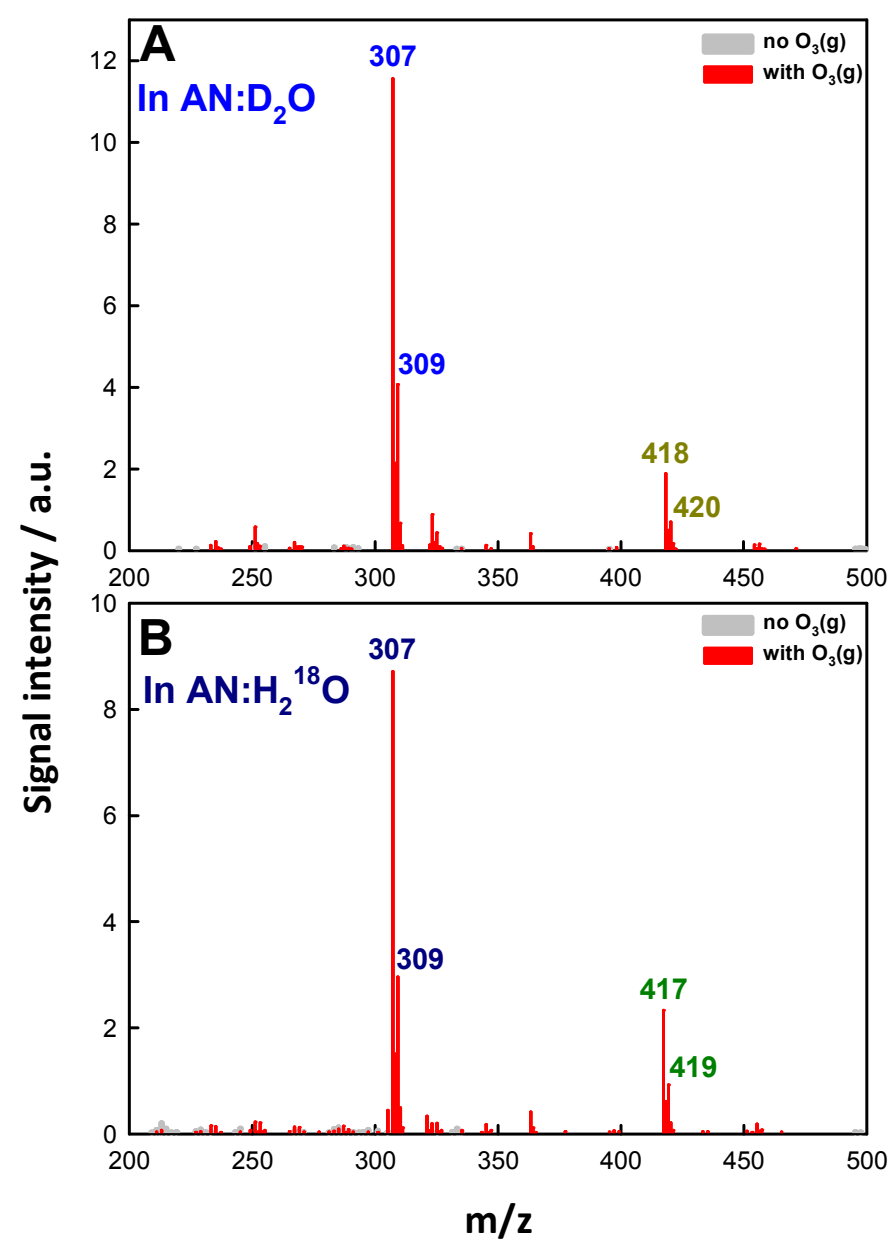

Figure 3 -Negative ion electrospray mass spectra of: (A) [1 $\mathrm{mM} \beta-\mathrm{C}+1 \mathrm{mM} \mathrm{NaCl}+100 \mathrm{mM}$ 1-octanol] in $\mathrm{AN}: \mathrm{D}_{2} \mathrm{O}$ (4:1=vol:vol) microjets, (B) $[1 \mathrm{mM} \beta-\mathrm{C}+1.3 \mathrm{mM} \mathrm{NaCl}+100 \mathrm{mM}$ 1-octanol $]$ in $\mathrm{AN}: \mathrm{H}_{2}{ }^{18} \mathrm{O}$ (4:1=vol:vol) microjets before (gray) and after (red) being exposed to $O_{3}(g)\left(E=1.4 \times 10^{11}\right.$ molecules $\mathrm{cm}^{-3}$ s).

It is apparent that the $\mathrm{m} / \mathrm{z}=305 ; 307$ product signals shift by +2 mass units into $307 ; 309$ signals in both $\mathrm{AN}: \mathrm{D}_{2} \mathrm{O}$ and $\mathrm{AN}: \mathrm{H}_{2}{ }^{18} \mathrm{O}$ (Fig. 3), in accordance with the formation of $\alpha$-hydroxy-hydroperoxides possessing two exchangeable hydroxylic $\mathrm{H}$-atoms via the incorporation of a single water molecule (Scheme 1). ${ }^{18}$ The observation that the $\mathrm{m} / \mathrm{z}=$ $417 ; 419$ product signals shift by +1 mass unit into $418 ; 420$ signals in $\mathrm{AN}: \mathrm{D}_{2} \mathrm{O}$ (Fig. $3 \mathrm{~A}$ ), but do not shift in $\mathrm{AN}: \mathrm{H}_{2}{ }^{18} \mathrm{O}$ (Fig. $3 \mathrm{~B}$ ) is consistent with the formation of $\alpha$-alkoxy-hydroperoxides 
(ethers) having a single exchangeable (OO)-H atom (see Scheme 1).

Since the hydrophobic $\mathrm{C}_{23}$-ether products ( $\mathrm{MW} 382$, detected as $\mathrm{m} / \mathrm{z} 417$ and 419 ) still have one (in the case of $\beta-\mathrm{C}$ ) and two (for $\alpha-\mathrm{H}) \mathrm{C}=\mathrm{C}$ double bond(s), they would be further ozonolyzed leading to higher $\mathrm{O} / \mathrm{C}$ ratio products. ${ }^{18}$ Ethers possessing hydroperoxide $-\mathrm{OOH}$ groups could propagate further polymerizations, as indicated above. ${ }^{3,7,51,60}$ Such processes are deemed to contribute to the formation of the exceedingly low-volatility organic compounds (ELVOCS) detected in recent field studies of tropospheric aerosols. ${ }^{23,53,61-62}$ Related high molecular weight species were also observed as major products in aerosols produced in the laboratory via $\alpha$-pinene ozonolysis, and in aerosols collected over boreal forests. $^{50,53}$

Fig. 4 shows electrospray mass spectral signals acquired from $[1 \mathrm{mM} \beta-\mathrm{C}+0.2 \mathrm{mM} \mathrm{NaCl}+$ $100 \mathrm{mM}$ 1-octanol] in $\mathrm{AN}: \mathrm{W}(4: 1)$ microjets exposed to gaseous $\mathrm{O}_{3} / \mathrm{O}_{2}$ mixtures as functions of $\mathrm{O}_{3}(\mathrm{~g})$ exposure.

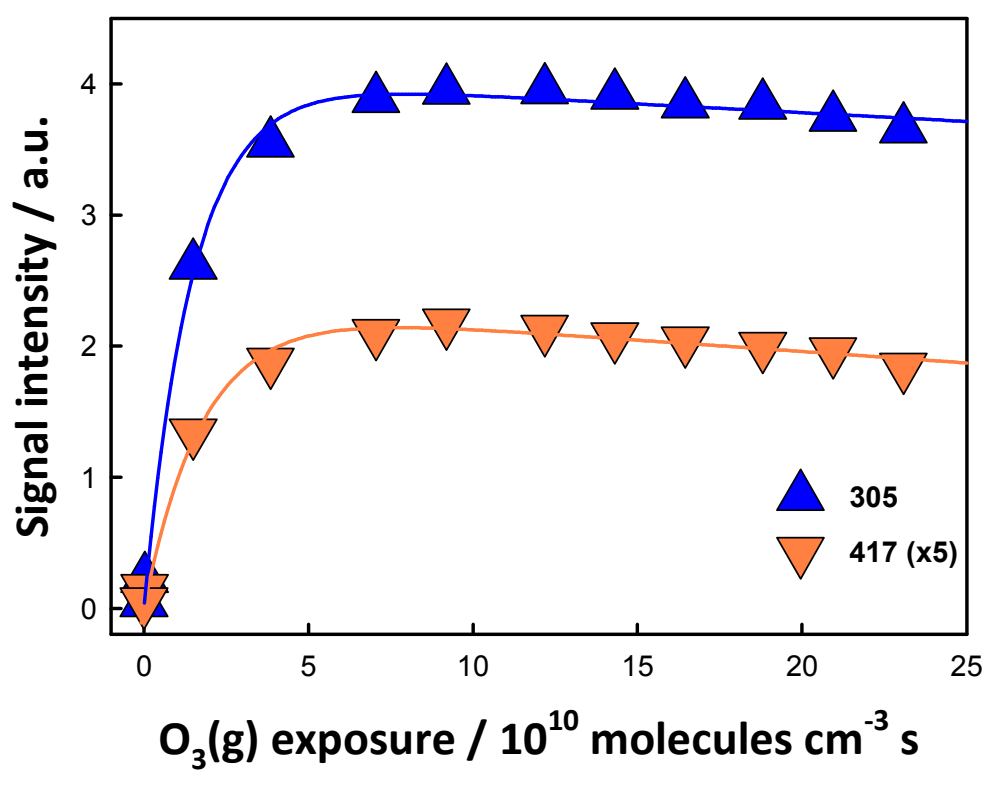

Figure 4 - Mass spectral signal intensities from $[1 \mathrm{mM} \beta-\mathrm{C}+0.2 \mathrm{mM} \mathrm{NaCl}+100 \mathrm{mM}$ 1-octanol] in $\mathrm{AN}: \mathrm{W}$ 
(4:1=vol:vol) microjets exposed to $\mathrm{O}_{3}(\mathrm{~g})$ as functions of $\mathrm{O}_{3}(\mathrm{~g})$ exposure (in $10^{10}$ molecules $\mathrm{cm}^{-3} \mathrm{~s}$ ). Plotted $\mathrm{m} / \mathrm{z} 417$ signal intensities are fivefold larger than actual values. The lines correspond to double exponential growth function regressions.

Both signals display non-zero initial slopes, as expected from early products generated within the first microseconds. The decline of $\mathrm{m} / \mathrm{z}=305$ and 417 signals above $E \sim 1 \times 10^{11}$ molecules $\mathrm{cm}^{-3} \mathrm{~s}$ implies that at that point unsaturated products begin to compete for ozone with partially depleted reactant sesquiterpenes in interfacial layers. ${ }^{18,63-64}$ This in turn implies that interfacial ozonolysis is faster than sesquiterpene diffusion from the bulk solution into interfacial layers. The key finding is that $\mathrm{Cls}$ react competitively with 1-octanol and interfacial $\left(\mathrm{H}_{2} \mathrm{O}\right)_{n}$ at significantly dissimilar bulk concentration ratios: [1-octanol] $/\left[\mathrm{H}_{2} \mathrm{O}\right]=$ $100 \mathrm{mM} / 23 \mathrm{M} \sim 10^{-2}$ (molar fraction of $\mathrm{H}_{2} \mathrm{O}: \mathrm{mf}_{\mathrm{W}}=0.42$, in $4: 1:: \mathrm{AN}: \mathrm{W}$ ).

We found that the reactivity of alcohols $\mathrm{C}_{n} \mathrm{H}_{2 n+1} \mathrm{OH}$ vs. $\mathrm{H}_{2} \mathrm{O}$ towards sesquiterpene $\mathrm{Cls}$ at the air-aqueous interface is a strongly increasing function of $n$. We quantified the competition between $\mathrm{C}_{n} \mathrm{H}_{2 n+1} \mathrm{OH}$ vs. $\mathrm{H}_{2} \mathrm{O}$ by the ratio of the mass spectral signal intensities: $m / z=X=204+48+M W\left(C_{n} H_{2 n+1} O H\right)+35 / 37$, of the $C_{15+n}$ ether products of $C_{n} H_{2 n+1} O H$ reactions with Cls vs. over the $\mathrm{m} / \mathrm{z} 305$ signal intensity of the product of Cls reaction with $\mathrm{H}_{2} \mathrm{O}: \mathrm{X} / 305$ and $\ln (\mathrm{X} / 305)$ as a function of $n$ at constant $\mathrm{O}_{3}(\mathrm{~g})$ exposure (Fig. 5). 

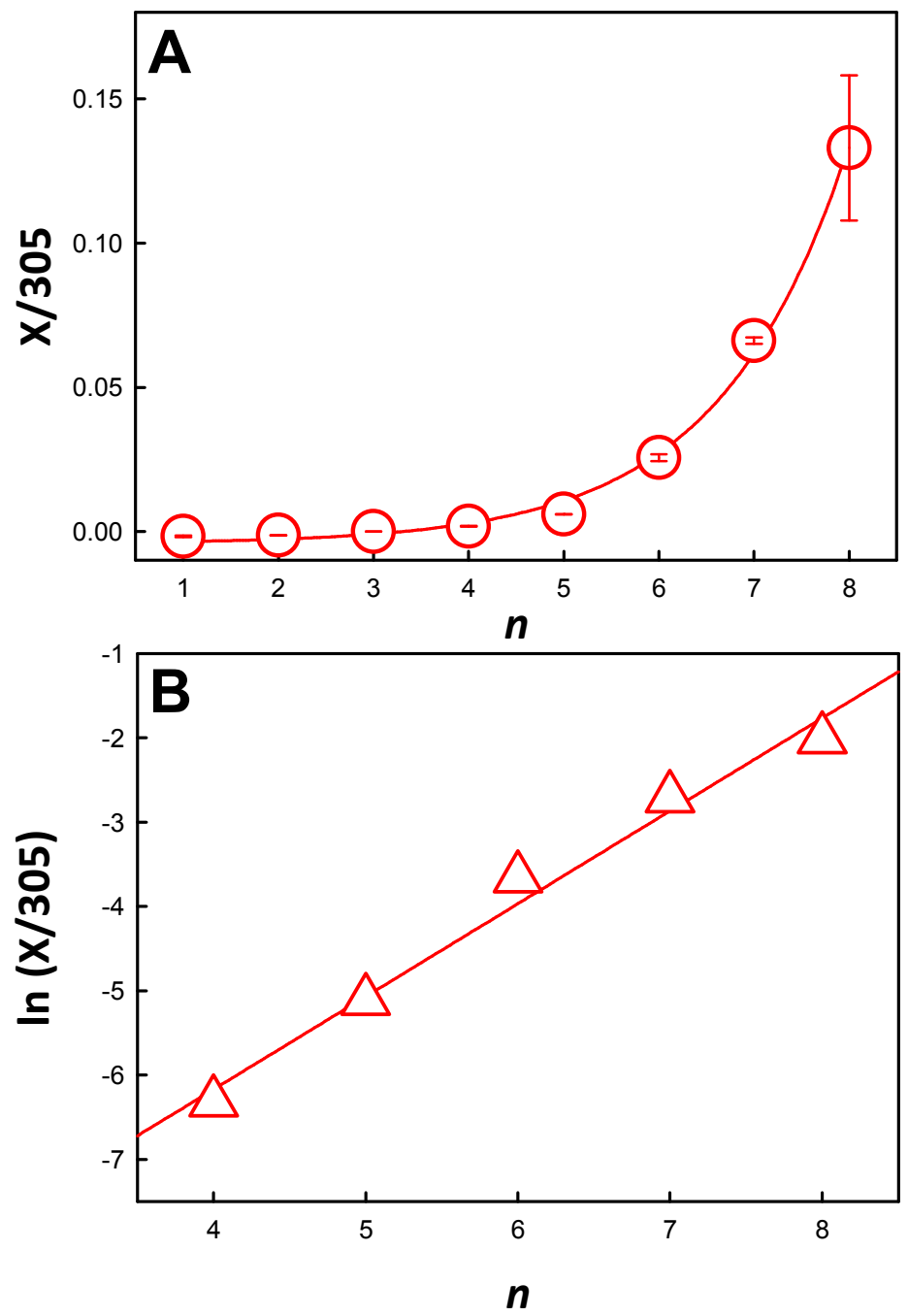

Figure $5-A)$ The $X / 305$ ratio of signal intensities and $B) \ln (X / 305)$ from $[1 \mathrm{mM} \beta-C+0.2 \mathrm{mM} \mathrm{NaCl}+100$ $\mathrm{mM} \mathrm{C}_{\mathrm{n}} \mathrm{H}_{2 \mathrm{n}+1} \mathrm{OH}$ ) in AN:W $(4: 1=$ vol:vol $)$ microjets exposed to $\mathrm{O}_{3}(\mathrm{~g})\left(E \approx 1.4 \times 10^{11}\right.$ molecules $\left.\mathrm{cm}^{-3} \mathrm{~s}\right)$ as a function of $n$. X $=319,333,347,361,375,389,403$, and 417 for $n=1,2,3,4,5,6,7$, and 8, respectively. Error bars are derived from duplicate measurements. The line corresponds to a single exponential growth function regression.

The fact that the $\mathrm{X} / 305$ ratio is a strongly increasing function of $n$ is consistent with the larger propensity of the longer alkyl chain alcohols for interfacial layers, ${ }^{65-66}$ and represent direct evidence that our experiments indeed probe interfacial events. The small $n \leq 3$ alcohols in fact did not generate detectable X signals (i.e., within background noise levels). 
Our results evoke a recent heterodyne-detected vibrational sum frequency generation (HD-VSFG) study, which revealed that whereas $\mathrm{C}_{n} \mathrm{H}_{2 n+1} \mathrm{OH}(\mathrm{n}<4)$ do not affect the structure and orientation of water at the air-water interface, the longer chain $\mathrm{C}_{n} \mathrm{H}_{2 n+1} \mathrm{OH}(n>4)$ alcohols enhance $\mathrm{H}$-bonding and force $\mathrm{H}_{2} \mathrm{O}$ molecules to point their $\mathrm{H}$-atoms to the gas-phase. ${ }^{66}$ Recently, Walz et al. showed, by using X-ray photoelectron spectroscopy (XPS), that $\mathrm{C}_{n} \mathrm{H}_{2 n+1} \mathrm{OH}$ interfacial affinities exponentially increase as a function of $n$. They reported free energies of $\mathrm{C}_{n} \mathrm{H}_{2 n+1} \mathrm{OH}$ adsorption to the air-water interface $\Delta G_{A d s}(n)$, which range from -15 to $-19 \mathrm{~kJ} \mathrm{~mol}^{-1}$ for $\mathrm{n}=4$ to 6 , respectively. ${ }^{65}$ Similarly, we recently determined that the stabilization energy of $\mathrm{R}_{\mathrm{n}}-\mathrm{COOH}$ ( $n$-alkanoic acids, $2 \leq \mathrm{n} \leq 7$ ) at the air-water interface increases by $\approx-0.8 \mathrm{~kJ} \mathrm{~mol}^{-1}$ per additional $-\mathrm{CH}_{2}$ - group. ${ }^{32}$

However, the gas-phase acidity of alcohols also increases exponentially with $n$ (see below). ${ }^{67-68}$ In this regard, we found that the $X / 305$ values in Fig. 5 are $\sim 20$ times smaller than those we previously reported for the corresponding products of $\mathrm{Cls}+\mathrm{R}_{n}-\mathrm{COOH}$ reactions on a molecular basis. ${ }^{18}$ This effect is clearly apparent in Fig. 6, which shows negative ion electrospray mass spectra of $[1 \mathrm{mM} \beta-\mathrm{C}+0.2 \mathrm{mM} \mathrm{NaCl}+100 \mathrm{mM}$ 1-octanol + $100 \mathrm{mM}$ n-octanoic acid (OA, MW 144)] in AN:W (4:1=vol:vol) microjets in the absence and presence of $\mathrm{O}_{3}(\mathrm{~g})$. 


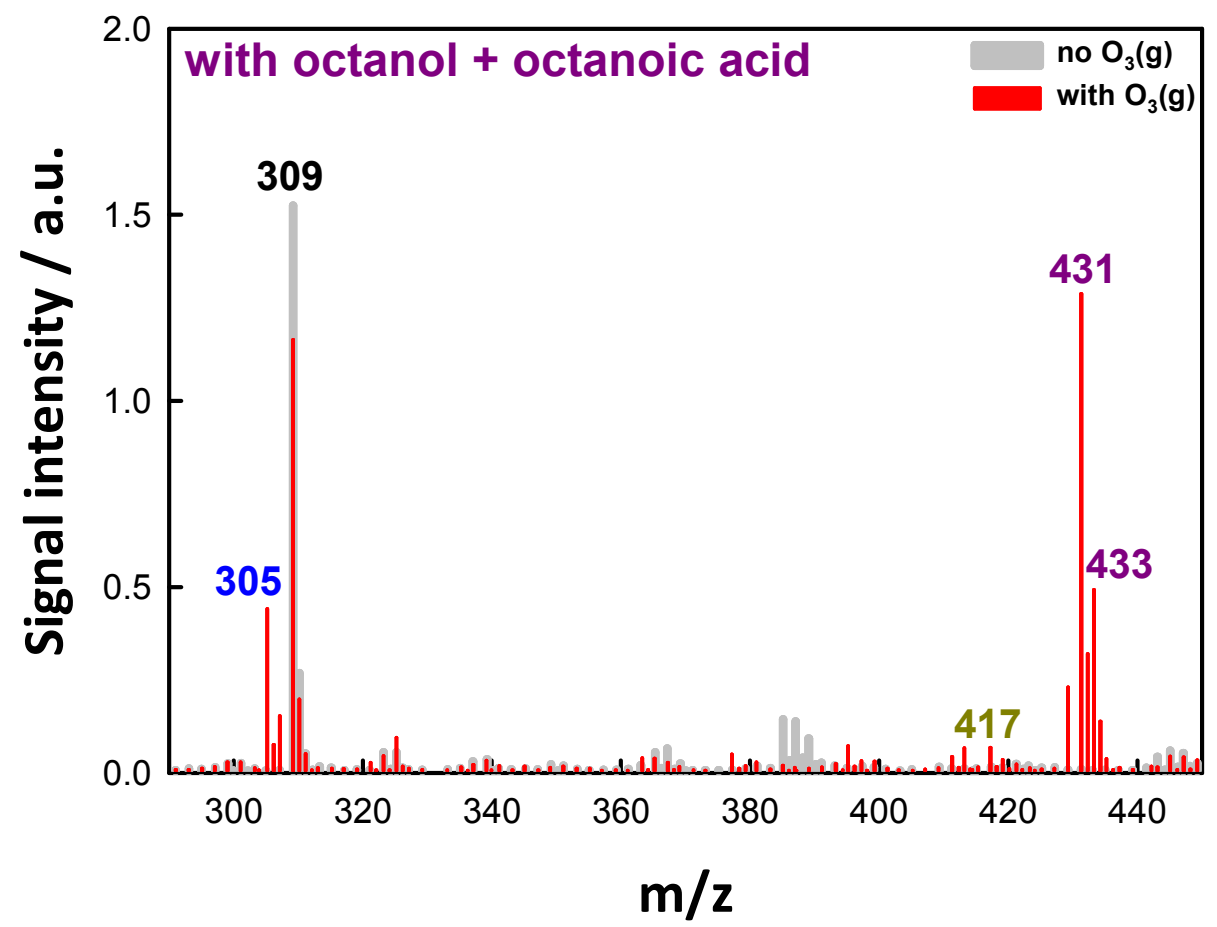

Figure 6 - Negative ion electrospray mass spectra of $[1 \mathrm{mM} \beta-\mathrm{C}+0.2 \mathrm{mM} \mathrm{NaCl}+100 \mathrm{mM}$ 1-octanol +100 $\mathrm{mM}$ n-octanoic acid] in AN:W (4:1=vol:vol) microjets before (gray) and after (red) being exposed to $\mathrm{O}_{3}(\mathrm{~g})$ $\left(E=2.3 \times 10^{11}\right.$ molecules $\left.\mathrm{cm}^{-3} \mathrm{~s}\right)$ in $1 \mathrm{~atm} \mathrm{~N}_{2}(\mathrm{~g})$ at $298 \mathrm{~K}$. The $\mathrm{m} / \mathrm{z} 309$ and 431;433 signals correspond to $\mathrm{Na}(\mathrm{OA})_{2}{ }^{-}$and $\alpha$-acyloxy-hydroperoxides $\left(\mathrm{C}_{23}\right.$ esters) from the $\mathrm{Cls}+\mathrm{OA}$ reaction, respectively. See text for details.

The peaks at $\mathrm{m} / \mathrm{z} 431$ and 433 correspond to $\mathrm{C}_{23}$ esters produced from OA addition to $\mathrm{Cls:}$ $431(433)=204+48+144+35(37) \cdot{ }^{18}$ Note that $\mathrm{OA}$ is inert toward $\mathrm{O}_{3}(\mathrm{~g})$ in the absence of $\mathrm{Cls}^{40}$ The observation that signal intensities at $\mathrm{m} / \mathrm{z} 417$ (and 419 ) from 1-octanol are $\sim 25$ times smaller than those at $\mathrm{m} / \mathrm{z} 431$ (and 433) from OA at [1-octanol] $=[\mathrm{OA}]=100 \mathrm{mM}$ reveals that 1-octanol is much less reactive than $\mathrm{OA}$ toward $\mathrm{Cls}$, although both species are expected to have similar affinities for aqueous surfaces. ${ }^{25,32,43,69-70}$ The $C_{23}$ ethers and esters produced in each case, by having similar mass and structures (see Scheme 1), are also expected to have similar interfacial affinities. Thus, the dissimilar mass spectral signal intensities in Fig. 6 are bona fide representations of the relative reactivities of n-alkanols vs 
n-alkanoic acids homologues toward Cls, and highlight the role of acidity in these processes. This finding is in line with gas-phase reaction rate constants of $\mathrm{Cls}+\mathrm{HCOOH} / \mathrm{CH}_{3} \mathrm{COOH}$, which approach collisionally controlled values: $k \geq 10^{-10} \mathrm{~cm}^{3}$ molecule $\mathrm{s}^{-1}{ }^{-12}$ vs. the much smaller values for $\mathrm{Cls}+$ methanol/2-propanol. ${ }^{48,50,68}$ Tobias and Ziemann have reported that rate constants of gas-phase $\mathrm{C}_{13} \mathrm{Cls}$ reactions with various species increase in the order: water $<$ methanol $<2$-propanol $<$ formaldehyde $<$ formic acid $<$ heptanoic acid, over a $10^{4}$ range. ${ }^{68}$ Remarkably, the reactivity of Cls toward these hydroxylic compounds is not determined by their $\mathrm{O}-\mathrm{H}$ bond dissociation energies but correlates with their gas-phase acidities, thereby suggesting polar transition states involving zwitterionic Cls. ${ }^{68}$ Our results are in excellent accordance with Tobias and Ziemann's findings, and strongly suggests that Cls reactions with hydroxylic compounds at gas-aqueous interfaces proceed by a similar mechanism. This is confirmed by Fig. 7 , where we plotted $\ln (X / 305)$ vs. gas-phase $\Delta G_{\text {acidity }}$ values for $\mathrm{C}_{n} \mathrm{H}_{2 n+1} \mathrm{OH}(n \geq 4)$ alcohols. Recall that gas-phase acidity is the negative of the Gibbs free energy associated with deprotonation, i.e., the smaller absolute $\Delta G_{\text {acidity }}$ values correspond to the more acidic species. The exponential dependence of $X$ with gas-phase $\Delta G_{\text {acidity }}$ values for $\mathrm{C}_{n} \mathrm{H}_{2 n+1} \mathrm{OH}(\mathrm{n}=1-8)$, which range from $1563 \mathrm{~kJ} \mathrm{~mol}^{-1}(\mathrm{n}=1)$ to $1525 \mathrm{~kJ} \mathrm{~mol}^{-1}$ $(n=8)$, is consistent with Tobias and Ziemann's findings and suggest similar reaction media in both cases, supporting our argument that the low water density at air-aqueous interfaces is a key factor underlying our observations. ${ }^{68}$ From this perspective, the results of Fig. 6 are consistent with the smaller gas-phase $\Delta G_{\text {acidity }}$ values for the $n$-alkanoic acids vs those for the n-alkanols: $\Delta G_{\text {acidity }}=1429 \mathrm{~kJ} \mathrm{~mol}^{-1}(\mathrm{n}=1)$ to $1418 \mathrm{~kJ} \mathrm{~mol}^{-1}(\mathrm{n}=6)$ for $\mathrm{R}_{\mathrm{n}}-\mathrm{COOH} .^{67,68,71}$ 


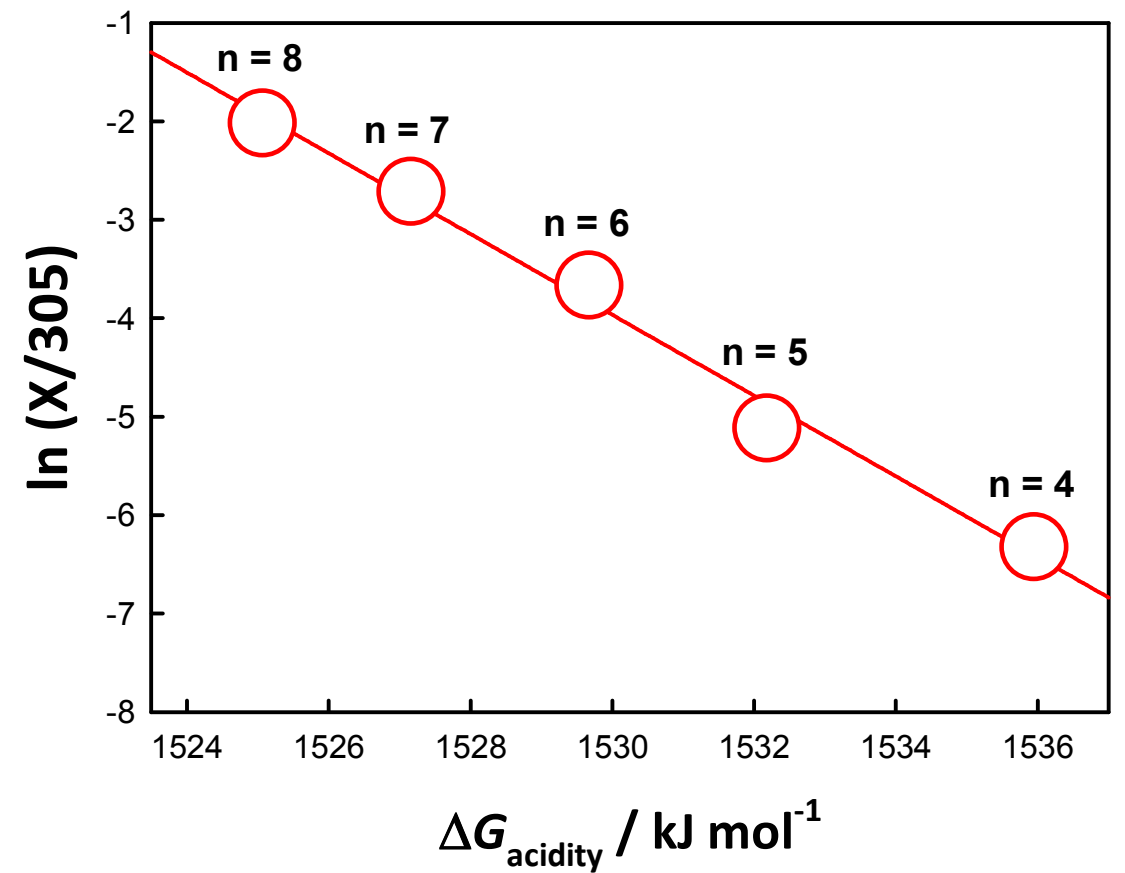

Figure 7 - $\mathrm{A}$ In $(\mathrm{X} / 305)$ plot from [1 $\left.\mathrm{mM} \beta-\mathrm{C}+0.2 \mathrm{mM} \mathrm{NaCl}+100 \mathrm{mM} \mathrm{C}_{n} \mathrm{H}_{2 n+1} \mathrm{OH}(\mathrm{n} \geq 4)\right]$ in AN:W (4:1 = vol:vol) microjets exposed to $\mathrm{O}_{3}(\mathrm{~g})\left(E \approx 1.4 \times 10^{11}\right.$ molecules $\left.\mathrm{cm}^{-3} \mathrm{~s}\right)$ as a function of gas-phase $\Delta G_{\text {acidity }}$ values from Ref 67.

Thus, the significant $\Delta G_{\text {acidity }}$ differences $\left(\geq 100 \mathrm{~kJ} \mathrm{~mol}^{-1}\right.$ ) between alcohols vs. carboxylic acids is what determines their relative reactivities towards $\mathrm{Cls}$. Therefore, both the increasing interfacial affinities and acidities of the larger $\mathrm{C}_{n} \mathrm{H}_{2 n+1} \mathrm{OH}$ mostly contribute to the strong $\mathrm{X} / 305$ vs. $n$ dependence in Fig. 5 .

Our experiments simulate a rapid ozonolysis process in which $\mathrm{O}_{3}(\mathrm{~g})$ initially sticks to the surface of aqueous organic aerosols in the presence of unsaturated hydrocarbons and ubiquitous alcohols. We found that the heterogenous ozonolysis of a solution of sesquiterpenes plus $n$-alkanols in $\mathrm{AN}: \mathrm{W}$ leads to higher mass products, such as $\alpha$-hydroxy-hydroperoxides and $\alpha$-alkoxy-hydroperoxides $\left(C_{15+n}\right.$ ethers). Since long-chain alcohols are ubiquitous amphiphilic species found in atmospheric aerosols and sea-surface microlayers, ${ }^{24-28}$ the interfacial chemistry on Cls involving alcohols would contribute to the 
growth/augmentation of atmospheric particles and to the formation of increasingly complex organic microfilms.

\section{Conclusion}

Our experiments show that Criegee intermediates produced in the ozonolysis of sesquiterpenes in the interfacial layers of aqueous organic media react with long-chain $\mathrm{C}_{n} \mathrm{H}_{2 n+1} \mathrm{OH}(\mathrm{n} \geq 4)$ alkanols to produce high mass species $\left(\mathrm{C}_{15+n}\right.$ ethers). Our results suggest that the reduced water concentration in interfacial layers relative to the bulk liquid makes amphiphilic components of aqueous organic aerosol competitive substrates for Criegee intermediates generated therein. The Cls chemistry we observe on aqueous organic surfaces provides direct pathways to exceedingly low-volatility organic compounds (ELVOCs). From this perspective, our findings provide new insights into how to narrow down the mismatch between field observations and atmospheric model calculations regarding the evolution of chemical complexity in organic aerosols. We found that among $C_{n}$ hydroxylic molecules, alcohols are significantly less reactive than carboxylic acids towards $\mathrm{Cls}$, and show that their reactivities depend both on interfacial affinities and gas-phase acidities.

\section{SUPPORTING INFORMATION}

Additional experimental data. This material is available free of charge via the Internet.

\section{Author Contributions}

S.E. designed and performed research; S.E and A.J.C. analyzed data and wrote the paper.

\section{ACKNOWLEDGEMENTS}

We acknowledge Drs. Satoshi Inomata, Akihiro Fushimi, Kei Sato of NIES, and Prof. Yosuke 
Sakamoto of Kyoto University. This work is partly supported by the research foundation for opto-science and technology, JSPS KAKENHI grant numbers $15 \mathrm{H} 05328$ and $15 \mathrm{~K} 12188$.

\section{REFERENCES}

1. Criegee, R., Mechanism of Ozonolysis. Angew. Chem. Internat. Edit. 1975, 14, 745-752.

2. Hatakeyama, S.; Akimoto, H., Reactions of Criegee Intermediates in the Gas-Phase. Res. Chem. Intermed. 1994, 20, 503-524.

3. Sakamoto, Y.; Yajima, R.; Inomata, S.; Hirokawa, J., Water Vapour Effects on Secondary Organic Aerosol Formation in Isoprene Ozonolysis. Phys. Chem. Chem. Phys. 2017, 19, 3165-3175.

4. Nguyen, T. B., et al., Atmospheric Fates of Criegee Intermediates in the Ozonolysis of Isoprene. Phys. Chem. Chem. Phys. 2016, 18, 10241-10254.

5. Yao, L.; Ma, Y.; Wang, L.; Zheng, J.; Khalizov, A.; Chen, M. D.; Zhou, Y. Y.; Qi, L.; Cui, F. P., Role of Stabilized Criegee Intermediate in Secondary Organic Aerosol Formation from the Ozonolysis of Alpha-Cedrene. Atmos. Environ. 2014, 94, 448-457.

6. Taatjes, C. A.; Shallcross, D. E.; Percival, C. J., Research Frontiers in the Chemistry of Criegee Intermediates and Tropospheric Ozonolysis. Phys. Chem. Chem. Phys. 2014, 16, 1704-1718.

7. Sakamoto, Y.; Inomata, S.; Hirokawa, J., Oligomerization Reaction of the Criegee Intermediate Leads to Secondary Organic Aerosol Formation in Ethylene Ozonolysis. J. Phys. Chem. A 2013, 117, 12912-12921.

8. Mauldin, R. L.; Berndt, T.; Sipila, M.; Paasonen, P.; Petaja, T.; Kim, S.; Kurten, T.; Stratmann, F.; Kerminen, V. M.; Kulmala, M., A New Atmospherically Relevant Oxidant of Sulphur Dioxide. Nature 2012, 488, 193-196.

9. Beck, M.; Winterhalter, R.; Herrmann, F.; Moortgat, G. K., The Gas-Phase Ozonolysis of Alpha-Humulene. Phys. Chem. Chem. Phys. 2011, 13, 10970-11001.

10. Winterhalter, R.; Herrmann, F.; Kanawati, B.; Nguyen, T. L.; Peeters, J.; Vereecken, L.; Moortgat, G. K., The Gas-Phase Ozonolysis of Beta-Caryophyllene $\left(\mathrm{C}_{15} \mathrm{H}_{24}\right)$. Part I: An Experimental Study. Phys. Chem. Chem. Phys. 2009, 11, 4152-4172.

11. Huang, H. L.; Chao, W.; Lin, J. J. M., Kinetics of a Criegee Intermediate That Would Survive High Humidity and May Oxidize Atmospheric So2. Proc. Nat1. Acad. Sci. U. S. A. 2015, 112, 10857-10862.

12. Matsuoka, K.; Sakamoto, Y.; Hama, T.; Kajii, Y.; Enami, S., Reactive Uptake of Gaseous Sesquiterpenes on Aqueous Surfaces. J. Phys. Chem. A 2017, 121, 810-818.

13. Enami, S.; Mishra, H.; Hoffmann, M. R.; Colussi, A. J., Protonation and Oligomerization of Gaseous Isoprene on Mildly Acidic Surfaces: Implications for Atmospheric Chemistry. J. Phys. 
Chem. A 2012, 116, 6027-6032.

14. Enami, S.; Hoffmann, M. R.; Colussi, A. J., Dry Deposition of Biogenic Terpenes via Cationic Oligomerization on Environmental Aqueous Surfaces. J. Phys. Chem. Lett. 2012, 3, 3102-3108.

15. Spielmann, F.; Langebner, S.; Ghirardo, A.; Hansel, A.; Schnitzler, J. P.; Wohlfahrt, G., Isoprene and Alpha-Pinene Deposition to Grassland Mesocosms. Plant Soil 2017, 410, 313-322.

16. Potier, E.; Loubet, B.; Durand, B.; Flura, D.; Bourdat-Deschamps, M.; Ciuraru, R.; Ogée, J., Chemical Reaction Rates of Ozone in Water Infusions of Wheat, Beech, Oak and Pine Leaves of Different Ages. Atmos. Environ. 2017, 151, 176-187.

17. Zhu, C. Q.; Kumar, M.; Zhong, J.; Li, L.; Francisco, J. S.; Zeng, X. C., New Mechanistic Pathways for Criegee-Water Chemistry at the Air/Water Interface. J. Am. Chem. Soc. 2016, 138, 11164-11169.

18. Enami, S.; Colussi, A. J., Criegee Chemistry on Aqueous Organic Surfaces. J. Phys. Chem. Lett. 2017, 8, 1615-1623.

19. Enami, S.; Colussi, A. J., Efficient Scavenging of Criegee Intermediates on Water by Surface-Active Cis-Pinonic Acid. Phys. Chem. Chem. Phys. 2017, DOI: 10.1039/C7CP03869K.

20. Long, B.; Bao, J. L.; Truhlar, D. G., Atmospheric Chemistry of Criegee Intermediates: Unimolecular Reactions and Reactions with Water. J. Am. Chem. Soc. 2016, 138, 14409-14422.

21. Lee, Y. P., Perspective: Spectroscopy and Kinetics of Small Gaseous Criegee Intermediates. J. Chem. Phys. 2015, 143, 020901.

22. Welz, O., et al., Rate Coefficients of $\mathrm{C} 1$ and $\mathrm{C} 2$ Criegee Intermediate Reactions with Formic and Acetic Acid near the Collision Limit: Direct Kinetics Measurements and Atmospheric Implications. Angew. Chem. Int. Edit. 2014, 53, 4547-4550.

23. Barsanti, K. C.; Kroll, J. H.; Thornton, J. A., Formation of Low-Volatility Organic Compounds in the Atmosphere: Recent Advancements and Insights. J. Phys. Chem. Lett. 2017, 8, 1503-1511.

24. Donaldson, D. J.; Vaida, V., The Influence of Organic Films at the Air-Aqueous Boundary on Atmospheric Processes. Chem. Rev. 2006, 106, 1445-1461.

25. Gilman, J. B.; Eliason, T. L.; Fast, A.; Vaida, V., Selectivity and Stability of Organic Films at the Air-Aqueous Interface. J. Colloid Interface Sci. 2004, 280, 234-243.

26. Fu, P. Q.; Kawamura, K.; Okuzawa, K.; Aggarwal, S. G.; Wang, G. H.; Kanaya, Y.; Wang, Z. F., Organic Molecular Compositions and Temporal Variations of Summertime Mountain Aerosols over Mt. Tai, North China Plain. J. Geophys. Res. Atmos. 2008, 113, D19107.

27. Donaldson, D. J.; George, C., Sea-Surface Chemistry and Its Impact on the Marine Boundary Layer. Environ. Sci. Technol. 2012, 46, 10385-10389.

28. Donaldson, D. J.; Valsaraj, K. T., Adsorption and Reaction of Trace Gas-Phase Organic Compounds on Atmospheric Water Film Surfaces: A Critical Review. Environ. Sci. Technol. 2010, $44,865-873$.

29. Enami, S.; Sakamoto, Y.; Colussi, A. J., Fenton Chemistry at Aqueous Interfaces. Proc. Natl. Acad. Sci. U. S. A. 2014, 111, 623-628. 
30. Enami, S.; Hoffmann, M. R.; Colussi, A. J., Prompt Formation of Organic Acids in Pulse Ozonation of Terpenes on Aqueous Surfaces. J. Phys. Chem. Lett. 2010, 1, 2374-2379.

31. Enami, S.; Colussi, A. J., Long-Range Hofmeister Effects of Anionic and Cationic Amphiphiles. J. Phys. Chem. B 2013, 117, 6276-6281.

32. Enami, S.; Fujii, T.; Sakamoto, Y.; Hama, T.; Kajii, Y., Carboxylate Ion Availability at the Air-Water Interface. J. Phys. Chem. A 2016, 120, 9224-9234.

33. Enami, S.; Hoffmann, M. R.; Colussi, A. J., Proton Availability at the Air/Water Interface. J. Phys. Chem. Lett. 2010, 1, 1599-1604.

34. Perrine, K. A.; Van Spyk, M. H.; Margarella, A. M.; Winter, B.; Faubel, M.; Bluhm, H.; Hemminger, J. C., Characterization of the Acetonitrile Aqueous Solution/Vapor Interface by Liquid-Jet X-Ray Photoelectron Spectroscopy. J. Phys. Chem. C 2014, 118, 29378-29388.

35. Makowski, M. J.; Stern, A. C.; Hemminger, J. C.; Tobias, D. J., Orientation and Structure of Acetonitrile in Water at the Liquid-Vapor Interface: A Molecular Dynamics Simulation Study. J. Phys. Chem. C 2016, 120, 17555-17563.

36. Enami, S.; Colussi, A. J., Long-Range Specific Ion-Ion Interactions in Hydrogen-Bonded Liquid Films. J. Chem. Phys 2013, 138, 184706.

37. Enami, S.; Vecitis, C. D.; Cheng, J.; Hoffmann, M. R.; Colussi, A. J., Electrospray Mass Spectrometric Detection of Products and Short-Lived Intermediates in Aqueous Aerosol Microdroplets Exposed to a Reactive Gas. J. Phys. Chem. A 2007, 111, 13032-13037.

38. Enami, S.; Hoffmann, M. R.; Colussi, A. J., How Phenol and Alpha-Tocopherol React with Ambient Ozone at Gas/Liquid Interfaces. J. Phys. Chem. A 2009, 113, 7002-7010.

39. Enami, S.; Hoffmann, M. R.; Colussi, A. J., Extensive H-Atom Abstraction from Benzoate by OH-Radicals at the Air-Water Interface. Phys. Chem. Chem. Phys. 2016, 18, 31505-31512.

40. Enami, S.; Hoffmann, M. R.; Colussi, A. J., In Situ Mass Spectrometric Detection of Interfacial Intermediates in the Oxidation of $\mathrm{RCOOH}(\mathrm{aq})$ by Gas-Phase OH-Radicals. J. Phys. Chem. A 2014, 118, 4130-4137.

41. Hoigne, J.; Bader, H.; Haag, W. R.; Staehelin, J., Rate Constants of Reactions of Ozone with Organic and Inorganic-Compounds in Water 3. Inorganic-Compounds and Radicals. Water Res. 1985, 19, 993-1004.

42. Enami, S.; Vecitis, C. D.; Cheng, J.; Hoffmann, M. R.; Colussi, A. J., Global Inorganic Source of Atmospheric Bromine. J. Phys. Chem. A 2007, 111, 8749-8752.

43. Enami, S.; Sakamoto, Y., OH-Radical Oxidation of Surface-Active Cis-Pinonic Acid at the AirWater Interface. J. Phys. Chem. A 2016, 120, 3578-3587.

44. Ghalaieny, M.; Bacak, A.; McGillen, M.; Martin, D.; Knights, A. V.; O'Doherty, S.; Shallcross, D. E.; Percival, C. J., Determination of Gas-Phase Ozonolysis Rate Coefficients of a Number of Sesquiterpenes at Elevated Temperatures Using the Relative Rate Method. Phys. Chem. Chem. Phys. 2012, 14, 6596-6602.

45. Hoigne, J.; Bader, H., Rate Constants of Reactions of Ozone with Organic and 
Inorganic-Compounds in Water .1. Non-Dissociating Organic-Compounds. Water Res. 1983, 17, 173-183.

46. Larson, J. W.; McMahon, T. B., Fluoride and Chloride Affinities of Main Group Oxides, Fluorides, Oxofluorides, and Alkyls. Quantitative Scales of Lewis Acidities from Ion Cyclotron Resonance Halide-Exchange Equilibria. J. Am. Chem. Soc. 1985, 107, 766-773.

47. Bohringer, H.; Fahey, D. W.; Fehsenfeld, F. C.; Ferguson, E. E., Bond-Energies of the Molecules $\mathrm{H}_{2} \mathrm{O}, \mathrm{SO}_{2}, \mathrm{H}_{2} \mathrm{O}_{2}$, and $\mathrm{HCl}$ to Various Atmospheric Negative-Ions. J. Chem. Phys. 1984, 81, 2805-2810.

48. Neeb, P.; Horie, O.; Moortgat, G. K., Gas-Phase Ozonolysis of Ethene in the Presence of Hydroxylic Compounds. Int. J. Chem. Kinet. 1996, 28, 721-730.

49. Witkowski, B.; Gierczak, T., Analysis of $\alpha$-Acyloxyhydroperoxy Aldehydes with Electrospray Ionization-Tandem Mass Spectrometry (ESI-MSn). J. Mass Spectrom. 2013, 48, 79-88.

50. Lee, S.; Kamens, R. M., Particle Nucleation from the Reaction of Alpha-Pinene and $\mathrm{O}_{3}$. Atmos. Envrion. 2005, 39, 6822-6832.

51. Wang, M. Y.; Yao, L.; Zheng, J.; Wang, X. K.; Chen, J. M.; Yang, X.; Worsnop, D. R.; Donahue, N. M.; Wang, L., Reactions of Atmospheric Particulate Stabilized Criegee Intermediates Lead to High-Molecular-Weight Aerosol Components. Environ. Sci. Technol. 2016, 50, 5702-5710.

52. Witkowski, B.; Gierczak, T., Early Stage Composition of SOA Produced by Alpha-Pinene/Ozone Reaction: Alpha-Acyloxyhydroperoxy Aldehydes and Acidic Dimers. Atmos. Environ. 2014, 95, 59-70.

53. Kristensen, K.; Watne, Å. K.; Hammes, J.; Lutz, A.; Petäjä, T.; Hallquist, M.; Bilde, M.; Glasius, M., High-Molecular Weight Dimer Esters Are Major Products in Aerosols from $\alpha$-Pinene Ozonolysis and the Boreal Forest. Environ. Sci. Technol. Lett. 2016, 3, 280-285.

54. Tong, H.; Arangio, A. M.; Lakey, P. S. J.; Berkemeier, T.; Liu, F.; Kampf, C. J.; Brune, W. H.; Pöschl, U.; Shiraiwa, M., Hydroxyl Radicals from Secondary Organic Aerosol Decomposition in Water. Atmos. Chem. Phys. 2016, 16, 1761-1771.

55. Vidrio, E.; Phuah, C. H.; Dillner, A. M.; Anastasio, C., Generation of Hydroxyl Radicals from Ambient Fine Particles in a Surrogate Lung Fluid Solution. Environ. Sci. Technol. 2009, 43, 922-927.

56. Ruehl, C. R.; Wilson, K. R., Surface Organic Mono Layers Control the Hygroscopic Growth of Submicrometer Particles at High Relative Humidity. J. Phys. Chem. A 2014, 118, 3952-3966.

57. Müller, L.; Reinnig, M. C.; Naumann, K. H.; Saathoff, H.; Mentel, T. F.; Donahue, N. M.; Hoffmann, T., Formation of 3-Methyl-1,2,3-Butanetricarboxylic Acid via Gas Phase Oxidation of Pinonic Acid - A Mass Spectrometric Study of SOA Aging. Atmos. Chem. Phys. 2012, 12, 1483-1496.

58. Cheng, Y.; Brook, J. R.; Li, S. M.; Leithead, A., Seasonal Variation in the Biogenic Secondary Organic Aerosol Tracer Cis-Pinonic Acid: Enhancement Due to Emissions from Regional and Local Biomass Burning. Atmos. Environ. 2011, 45, 7105-7112. 
59. Zhang, Y. Y.; Muller, L.; Winterhalter, R.; Moortgat, G. K.; Hoffmann, T.; Poschl, U., Seasonal Cycle and Temperature Dependence of Pinene Oxidation Products, Dicarboxylic Acids and Nitrophenols in Fine and Coarse Air Particulate Matter. Atmos. Chem. Phys. 2010, 10, 7859-7873. 60. Riva, M.; Budisulistiorini, S. H.; Zhang, Z.; Gold, A.; Thornton, J. A.; Turpin, B. J.; Surratt, J. D., Multiphase Reactivity of Gaseous Hydroperoxide Oligomers Produced from Isoprene Ozonolysis in the Presence of Acidified Aerosols. Atmos. Environ. 2017, 152, 314-322.

61. Ehn, M., et al., A Large Source of Low-Volatility Secondary Organic Aerosol. Nature 2014, $506,476-479$.

62. Riccobono, F., et al., Oxidation Products of Biogenic Emissions Contribute to Nucleation of Atmospheric Particles. Science 2014, 344, 717-721.

63. Kjaergaard, H. G.; Kurten, T.; Nielsen, L. B.; Jorgensen, S.; Wennberg, P. O., Criegee Intermediates React with Ozone. J. Phys. Chem. Lett. 2013, 4, 2525-2529.

64. Vereecken, L.; Harder, H.; Novelli, A., The Reactions of Criegee Intermediates with Alkenes, Ozone, and Carbonyl Oxides. Phys. Chem. Chem. Phys. 2014, 16, 4039-4049.

65. Walz, M. M.; Werner, J.; Ekholm, V.; Prisle, N. L.; Ohrwall, G.; Bjorneholm, O., Alcohols at the Aqueous Surface: Chain Length and Isomer Effects. Phys. Chem. Chem. Phys. 2016, 18, 6648-6656.

66. Mondal, J. A.; Namboodiri, V.; Mathi, P.; Singh, A. K., Alkyl Chain Length Dependent Structural and Orientational Transformations of Water at Alcohol-Water Interfaces and Its Relevance to Atmospheric Aerosols. J. Phys. Chem. Lett. 2017, 8, 1637-1644.

67. Boand, G.; Houriet, R.; Gaumann, T., Gas-Phase Acidity of Aliphatic-Alcohols. J. Am. Chem Soc. 1983, 105, 2203-2206.

68. Tobias, H. J.; Ziemann, P. J., Kinetics of the Gas-Phase Reactions of Alcohols, Aldehydes, Carboxylic Acids, and Water with the C13 Stabilized Criegee Intermediate Formed from Ozonolysis of 1-Tetradecene. J. Phys. Chem. A 2001, 105, 6129-6135.

69. Donaldson, D. J.; Anderson, D., Adsorption of Atmospheric Gases at the Air-Water Interface. 2. C-1-C-4 Alcohols, Acids, and Acetone. J. Phys. Chem. A 1999, 103, 871-876.

70. Houriez, C.; Meot-Ner, M.; Masella, M., Simulated Solvation of Organic Ions II: Study of Linear Alkylated Carboxylate Ions in Water Nanodrops and in Liquid Water. Propensity for Air/Water Interface and Convergence to Bulk Solvation Properties. J. Phys. Chem. B 2015, 119, 12094-12107.

71. Caldwell, G.; Renneboog, R.; Kebarle, P., Gas-Phase Acidities of Aliphatic Carboxylic-Acids, Based on Measurements of Proton-Transfer Equilibria. Can. J. Chem. 1989, 67, 611-618. 


\section{n-Alkanols}

7

8

10

11

13

14
15

15
16

17

19

20
21

22

23

24

2

26

27

28

30

32

33

34

Criegee Intermediates

$C_{15+n}$ Ethers 